\title{
OPTIMASI WAKTU MASERASI PARASETAMOL DALAM JAMU \\ PEGAL LINU YANG BEREDAR DI BOGOR BARAT
}

\author{
Bina Lohita Sari ${ }^{1}$, Harry Noviardi ${ }^{2 *}$,Nur Apriani Kartini ${ }^{2}$ \\ ${ }^{1}$ Program Studi Farmasi, Fakultas Matematika dan Ilmu Pengetahuan Alam, Universitas Pakuan \\ ${ }^{2}$ Program Studi S1Farmasi, Sekolah Tinggi Teknologi Industri dan Farmasi, Bogor \\ Korespondensi: harry.noviardi@gmail.com
}

\begin{abstract}
ABSTRAK
Jamu merupakan obat tradisional yang sering dikonsumsi oleh masyarakat Indonesia.Salah satu produk jamu yang diminati adalah jamu pegal linu.Peraturan pemerintah menyatakan bahwa di dalam jamu tidak diperbolehkan terkandung bahan kimia sintetik obat atau hasil isolasi berkhasiat obat.Namun, pada kenyataannya masih terdapat jamu yang mengandung senyawa obat terutama parasetamol. Analisis bahan kimia obat dalam jamu belum disertai metode optimum yang menghasilkan kadar yang optimal. Penelitian ini bertujuan menentukan waktu optimal maserasi parasetamol dalam jamu dan menetapkan kadar parasetamol dalam jamu pegal linu yang beredar di Bogor Barat. Sampel diambil dengan metode purposive sampling. Proses maserasi menggunakan pelarut etanol dalam waktu yang bervariasi. Analisis dengan kromatografi lapis tipis menggunakan silika gel $\mathrm{GF}_{254}$ sebagai fase diam, kloroform:etanol (9:1) sebagai fase gerak dan dideteksi pada sinar UV $254 \mathrm{~nm}$. Hasil penelitian menunjukkan bahwa dari 10 sampel jamu, 7 sampel positif mengandung parasetamol. Waktu maserasi 0-30 menit optimum untuk jamu simulasi, sampel jamu $\mathrm{D}, \mathrm{F}$ dan $\mathrm{S}$ dengan kadar sebesar 2,49 hingga 22,33\%. Waktu maserasi selama 60-90 menit optimum untuk sampel A, E dan Q dengan kadar sebesar 4,47 hingga 7,12\%. Sampel H memiliki waktu maserasi optimum selama 120 menit dengan kadar sebesar $18,38 \%$. Waktu optimasi maserasi sampel didominasi oleh rentang waktu antara 30-90 menit.Oleh karena itu, diketahui bahwa sampel jamu pegal linu yang tersebar memiliki waktu maserasi yang optimal pada rentang waktu antara 30-90 menit.
\end{abstract}

Kata kunci: jamu pegal linu, maserasi, optimasi, parasetamol, waktu

\begin{abstract}
Jamu is a traditional medicine that is consumed by people. One type of herbal medicine on the market is Jamu Pegal Linu. Indonesian Govermment's rule that this traditional medicine may not contain any synthetic chemical substance or drug functioned isolated compound. In reality there are still found some jamu pegal linu that contain medicine compound especially paracetamol. Analyzis chemical of drugs in herbal medicine has not been accompanied by the optimum times extraction. The aim of research to optimize of the time maceration and determine the contained of paracetamol in jamu pegal linu had circulated in Bogor Barat. Sample was taken by purposive sampling. Maceration from samples were using ethanol were within varying. Analysis of thin layer chromatography was using silica gel $\mathrm{GF}_{254}$ as the stationary phase, chloroform:ethanol (9:1) as the mobile phase with short waved UV as detection method. The results showed that 7 samples contained paracetamol from 10 samples of jamu pegal linu. The optimum of the time maceration between 0-30 minutes for herbal optimum simulation, sample D, F and $\mathrm{S}$ with a concentration of 2,49 to $22,33 \%$. The optimum of the time maceration between $60-90$ minutes for the sample A, E and Q with levels of 4,47 to $7,12 \%$. Sample $H$ had the optimum maceration time for 120 minutes with a concentration of $18.38 \%$. Optimization of sample maceration time is dominated by the span of time between 30-90 minutes. Therefore, it is known that the samples of jamu pegal linu spread had maceration on the optimal time period between 30-90 minutes.
\end{abstract}

Keyword: jamu pegal linu, maceration, optimization, paracetamol, time 


\section{PENDAHULUAN}

Obat tradisional adalah bahan atau ramuan yang terbuat dari tumbuhan, hewan, mineral, sediaan sarian (galenik) atau campuran dari bahan tersebut yang secara turun temurun telah digunakan untuk pengobatan berdasarkan pada pengalaman.Salah satu contoh obat tradisional adalah jamu [1].

Jamu digunakan sejak dahulu secara luas oleh masyarakat Indonesia sebagai upaya untuk menjaga kesehatan maupun sebagai pengobatan suatu penyakit.Jamu banyak dikonsumsi oleh masyarakat karena kepercayaan masyarakat terhadap pengalaman turun temurun, aman, relatif tidak menunjukan efek samping yang berarti dan juga karena harganya relatif murah [2].

Salah satu produk obat tradisional yang banyak diminati oleh masyarakat adalah jamu pegal linu.Jamu pegal linu digunakan untuk menghilangkan pegal linu, nyeri otot dan tulang, memperlancar peredaran darah dan memperkuat daya tahan tubuh.Minat masyarakat yang besar terhadap produk jamu pegal linu sering disalahgunakan produsen jamu untuk menambahkan bahan kimia obat [2]. Sedangkan menurut Peraturan Menteri Kesehatan Republik Indonesia No. 007 Tahun 2012 tentang Registrasi Obat Tradisional Pasal 7 ayat 1 menyatakan bahwa obat tradisional dilarang mengandung bahan kimia obat yang merupakan hasil isolasi atau sintetik yang berkhasiat obat.

Berdasarkan pada hasil pengawasan Badan POM di seluruh Indonesia antara bulan Agustus dan November 2015, ditemukan 54 obat tradisional yang mengandung bahan kimia obat dan 47 diantaranya merupakan obat tradisional tanpa nomor izin edar/ilegal. Bahan kimia obat yang teridentifikasi dicampur dalam temuan produk obat tradisional pegal linu didominasi oleh penghilang rasa sakit seperti parasetamol [3].Parasetamol atau asetaminofen merupakan metabolit fenasetin dengan khasiat antipiretik dan analgetik lemah.Pada penggunaan kronis dari 3-4 gram sehari dapat mengakibatkan kerusakan hati dan pada dosis lebih dari 6 gram mengakibatkan nekrosis hati yang tidak reversibel [4].

Upaya pemberantasan obat tradisional mengandung bahan kimia obat yang dilakukan Badan POM tidak akan berjalan optimal tanpa dukungan pelaku usaha dan masyarakat termasuk peneliti. Penelitian yang dilakukan oleh Syadawi (2012) mengenai identifikasi jamu pegal linu yang beredar di kota Padang, menunjukkan bahwa dari 5 buah sampel jamu pegal linu terdapat 2 buah sampel yang mengandung parasetamol [5]. Pengembangan metode analisis parasetamol dan deksametason pada jamu pegal linu menggunakan metode ekstraksi fase padat dan kromatografi cair kinerja tinggi menunjukkan bahwa kedua metode tersebut memiliki hasil bercak yang tidak jelas pada Kromatografi Lapis Tipis (KLT). Oleh karena itu, tidak dapat dilakukan validasi metode kualitatif dan kuantitatif [6].

Dalam berbagai penelitian yang telah dilakukan, analisis bahan kimia obat dalam jamu belum disertai metode yang dapat menghasilkan hasil analisis berupa kadar yang optimal. Oleh karena itu, dilakukan optimasi waktu maserasi agar senyawa obat parasetamol dalam jamu pegal linu dapat terekstraksi lebih baik.Metode maserasi dipilih karena termasuk ke dalam metode yang cocok untuk senyawa obat yang tahan pemanasan maupun yang tidak tahan pemanasan dan hanya menggunakan satu macam pelarut [7].Hasil maserasi yang diperoleh dapat dianalisis secara kualitatif menggunakan Kromatografi Lapis Tipis dan secara kuantitatif menggunakan Spektrofotometri UV-Vis[8].Analisis kuantitatif dengan Spektrofotometri UV-Vis digunakan untuk mencegah penggunaan pelarut yang dapat merusak lingkungan.

\section{METODE PENELITIAN}

Bahan: jamu pegal linu blangko yang terdiri dari jahe (Zingiberis officinale Rhizoma), laos(Languatis Rhizoma), kunyit (Curcuma domesticae Rhizoma), akar manis(Glycyrrhizae Radix), temulawak(Curcuma xanthorrhiza Rhizoma), lempuyang gajah(Zingiberis zerumbeti Rhizoma), buah cabe jawa (Retrofracti Fructus) dan biji pala (Myristicae Semen) yang berasal dari Balai Penelitian Tanaman Obat dan Rempah Obat (BALITRO) Bogor. Standar parasetamol (Hebei Jiheng Pharmaceutical CO., LTD) diklorometana (p.a), metanol(p.a), aquades, etanol 96\% (p.a) dan jamu pegal linu yang beredar di wilayah Bogor Barat.

Alat: mikropipet, timbangan analitik (Ohaus), UV Light Viewing $254 \mathrm{~nm}$, lempeng KLT silika gel $60 \mathrm{~F}_{254}$, Chamber kaca, Spektrofotometer UV-Vis (Shimadzu UV mini-1240), magnetic stirrer, Tachometer (Tasi-8740) dan peralatan gelas. 


\section{Metode}

\section{Pembuatan Jamu Kontrol}

Jamu kontrol dibuat dengan komposisi berdasarkan penelitian Sudiarto (1999) yang terdiri atas jahe (Zingiberis officinale Rhizoma) $16,7 \%$, laos(Languatis Rhizoma)10,0 \%, kunyit (Curcuma domesticae Rhizoma) 16,7 \%, akar manis(Glycyrrhizae Radix)13,3 \%, temulawak(Curcuma xanthorrhiza Rhizoma)13,3\%, lempuyang gajah(Zingiberis zerumbeti Rhizoma)10,0 \%, buah cabe jawa (Retrofracti Fructus) 10,0 \% dan biji pala (Myristicae Semen) 10,0 \% sebanyak 100 gram [9].

\section{Pengambilan Sampel}

Pengambilan sampel dilakukan dengan metode purposive sampling, yaitu pengambilan sampel yang sudah direncanakan sesuai persyaratan.Sampel jamu pegal linu yang diperlukan berupa produk jamu pegal linu yang paling banyak dijual di toko jamu.Setelah itu, dilakukan survey jumlah toko dan produk jamu yang terdapat di wilayah Kecamatan Bogor Barat yang memiliki 16 kelurahan [10].

\section{Analisis Kualitatif menggunakan Kromatografi Lapis Tapis}

\section{Pembuatan Larutan Standar}

Sebanyak $100 \mathrm{mg}$ parasetamol standar dimasukkan ke dalam labu ukur 100 $\mathrm{mL}$.Setelah itu, labu ukur ditambahkan etanol hingga batas tera sehingga diperoleh larutan standar dengan konsentrasi sebesar 1000 ppm.

\section{Pembuatan Jamu Simulasi untuk Analisis Kualitatif}

Sebanyak $50 \mathrm{mg}$ parasetamol ditambahkan jamu kontrol hingga $500 \mathrm{mg}$, kemudian campuran tersebut digerus hingga homogen.Setelah itu, sediaan dimasukkan ke dalam labu ukur $25 \mathrm{~mL}$ dan ditambahkan etanol hingga batas tera.Larutan tersebut dikocok beberapa saat dan disaring menggunakan kertas saring.Hasil penyaringan dipekatkan pada suhu $70{ }^{\circ} \mathrm{C}$.

\section{Pemilihan Fase Gerak}

Percobaan dilakukan dengan menotolkan larutan standar parasetamol dan larutan jamu simulasi pada lempeng KLT sebanyak $1 \mu \mathrm{l}$, kemudian dielusi dengan fase gerak yang telah digunakan oleh beberapa acuan. Fase gerak yang digunakan pada penelitian sebelumnya, yaitu diklorometana:metanol dengan komposisi
4:1 [11], kloroform:metanol dengan komposisi 1:9 [5] dan kloroform:etanol dengan komposisi 9:1 [12] dalam kondisi jenuh.

Setelah elusi selesai, lempeng diangkat dan dibiarkan mengering lalu dilakukan pengamatan bercak oleh lampu UV dengan panjang gelombang $254 \mathrm{~nm}$. Bercak yang muncul, kemudian dihitung nilai $\mathrm{Rf}$ dan dipilih fase gerak yang paling baik, yaitu yang memiliki nilai $\mathrm{Rf}$ antara 0,3 dan 0,7 [13].

\section{Preparasi Sampel}

Sampel jamu pegal linu diambil per kapsul dan dimasukkan ke dalam labu ukur $20 \mathrm{~mL}$, kemudian ditambahkan etanol hingga batas tera.Setelah itu, larutan sampel disaring dan hasil penyaringan dipekatkan pada suhu $70{ }^{\circ} \mathrm{C}$.

\section{Analisis Kualitatif}

Masing-masing jamu sampel hasil pemekatan, kemudian ditotolkan pada lempeng KLT sebanyak $1 \mu \mathrm{l}$ dan pada lempeng yang sama juga ditotolkan larutan standar parasetamol. Selanjutnya, lempeng KLT dielusi dengan fase gerak terpilih.Setelah elusi selesai, lempeng diangkat dan dibiarkan mengering lalu dilakukan pengamatan bercak oleh lampu UV dengan panjang gelombang $254 \mathrm{~nm}$. Bercak yang muncul, kemudian dibandingkan antara nilai $\mathrm{Rf}$ bercak larutan sampel dan nilai $\mathrm{Rf}$ bercak larutan standar parasetamol. Jika nilai $\mathrm{Rf}$ mirip atau sama, maka larutan sampel yang diuji positif mengandung senyawa parasetamol.

\section{Analisis Kuantitatif menggunakan Spektrofotometer UV-Vis}

\section{Penentuan Panjang Gelombang Maksimum Parasetamol}

Sebanyak $100 \mathrm{mg}$ parasetamol standar dimasukkan ke dalam labu ukur $100 \mathrm{~mL}$ dan ditambahkan etanol hingga batas tera. Setelah itu, larutan standar parasetamol dibuat dengan konsentrasi sebesar $6 \mathrm{ppm}$ dan diukur absorbansnya pada panjang gelombang antara 200 dan $350 \mathrm{~nm}$ pada Spektrofotometer UV-Vis sehingga diperoleh panjang gelombang maksimum parasetamol [14].

\section{Pembuatan Deret Larutan Standar Parasetamol}

Sebanyak $100 \mathrm{mg}$ parasetamol standar dimasukkan ke dalam labu ukur $100 \mathrm{~mL}$ kemudian ditambahkan etanol hingga batas tera. Larutan tersebut diencerkan sehingga didapatkan konsentrasi deret larutan standar sebesar $0,2,3,4,5$ dan 6 ppm, kemudian 
dilakukan pengukuran nilai absorbans dengan menggunakan Spektrofotometer UV-Vis serta ditentukan linieritasnya [14].

\section{Pembuatan Jamu Simulasi}

Sebanyak $50 \mathrm{mg}$ parasetamol ditambahkan jamu kontrol hingga $300 \mathrm{mg}$. Campuran tersebut digerus dalam mortir hingga homogen.

\section{Uji Pendahuluan Optimasi Waktu Maserasi Parasetamol}

Jamu simulasi yang telah dibuat kemudian dimasukkan ke dalam labu ukur $25 \mathrm{~mL}$ dan ditambahkan etanol hingga batas tera. Setelah itu, campuran tersebut dimasukkan ke dalam erlenmeyer $100 \mathrm{~mL}$ dan dimaserasi dengan pengadukan menggunakan magnetic stirrer dengan kecepatan $560 \mathrm{rpm}$ pada variasi waktu 30, 60, 90, 120, 150 dan 180 menit. Hasil maserasi disaring menggunakan kertas saring dan filtrat yang diperoleh kemudian diencerkan hingga 500x.Setelah itu, dilakukan pengukuran nilai absorbans dari larutan tersebut menggunakan Spektrofotometer UV-Vis pada panjang gelombang maksimal parasetamol.Waktu maserasi yang menghasilkan nilai absorbans tertinggi adalah waktu optimal maserasi parasetamol dalam jamu pegal linu simulasi.

\section{Preparasi Sampel}

Sampel yang positif mengandung parasetamol pada analisis kualitatif menggunakan KLT kemudian ditimbang sebanyak $300 \mathrm{mg}$. Sampel tersebut dimasukkan ke dalam labu ukur $25 \mathrm{~mL}$ dan ditambahkan etanol hingga batas tera. Setelah itu, masingmasing larutan sampel dimasukkan ke dalam erlenmeyer $100 \mathrm{~mL}$ dan dimaserasi dengan pengadukan menggunakan magnetic stirrer dengan kecepatan $560 \mathrm{rpm}$ pada variasi waktu 30, 60, 90, 120, 150 dan 180 menit. Hasil maserasi disaring menggunakan kertas saring dan dilakukan pengenceran. Sampel D dan H diencerkan sebanyak 1000x, sampel E, Q dan S sebanyak 250x serta sampel F sebanyak 200x. Preparasi sampel dilakukan secara triplo.

\section{Analisis Kuantitatif}

Larutan sampel hasil maserasi, kemudian dianalisis menggunakan Spektrofotometri UVVis pada panjang gelombang maksimal parasetamol yang telah didapat pada uji pendahuluan. Nilai absorbans yang didapat kemudian digunakan dalam perhitungan persen kadar parasetamol dalam jamu pegal linu. Waktu maserasi yang menghasilkan nilai absorbans tertinggi adalah waktu optimal maserasi parasetamol dalam jamu pegal linu.

\section{HASIL DAN PEMBAHASAN}

\section{Jamu Pegal Linu}

Pengambilan sampel dilakukan dengan metode purposive sampling, yaitu pengambilan sampel yang dilakukan atas dasar pertimbangan peneliti dan sampel yang diambil dianggap telah mewakili suatu populasi [15].Menurut Dinas Perindustrian dan Perdagangan Kota Bogor, toko jamu yang tersebar di wilayah Bogor belum terdata secara resmi.Hal tersebut dikarenakan usaha toko jamu merupakan usaha yang sifatnya tidak permanen dan tergolong usaha kecil.Oleh karena itu, dilakukan survey langsung ke setiap toko jamu untuk mengetahui toko-toko jamu yang terdapat di wilayah Bogor Barat yang memiliki 16 kelurahan (Dinas Kota Bogor, 2016).Jamu kuat yang beredar di Bogor Barat cukup bervariatif.Sampel disurvei secara langsung pada 16 kelurahan wilayah Bogor Barat.Produk jamu pegal linu yang dijual terdapat 25 jenis produk yang memiliki komposisi berbeda-beda.

Pembuatan jamu pegal linu kontrol dan jamu simulasi dilakukan untuk mencari kondisi yang sesuai dalam jamu. Jamu kontrol, yaitu jamu pegal linu yang tidak mengandung senyawa obat dan dibuat berdasarkan penelitian Sudiarto (1999) dengan komposisi jamu yang terdiri atas Zingiberis officinale Rhizoma, Languatis Rhizoma, Curcuma domesticae Rhizoma, Glycyrrhizae Radix, Curcuma xanthorrhiza Rhizoma, Zingiberis zerumbeti Rhizoma, Retrofracti Fructus dan Myristicae Semen sebanyak 100 gram [9].Jamu simulasi, yaitu jamu pegal linu kontrol yang telah ditambahkan senyawa obat parasetamol.Jamu simulasi digunakan untuk menentukan rentang waktu maserasi parasetamol dalam jamu pegal linu dengan pengadukan konstan, digunakan dalam pemilihan fase gerak pada KLT dan digunakan sebagai pembanding terhadap sampel jamu pegal linu.Sampel jamu pegal linu yang dijadikan sampel adalah jamu pegal linu yang dijual lebih dari setengah jumlah toko yang ada. Sampel pegal linu yang telah disurvei sebanyak 10 jenis produk (Kode sampel: A, B, $\mathrm{C}, \mathrm{D}, \mathrm{E}, \mathrm{F}, \mathrm{H}, \mathrm{K}, \mathrm{Q}$ dan S) kemudian dimaserasi dengan rentang waktu tertentu sesuai dengan perlakuan terhadap jamu simulasi. 
Hasil Analisis Kualitatif Parasetamol

Metode Kromatografi Lapis Tipis merupakan salah satu metode kromatografi yang sering digunakan dalam menganalisis obat [16].Prinsip kerja KLT adalah memisahkan senyawa/analit berdasarkan pada kepolaran senyawa [16]. Pemilihan fase gerak terlebih dahulu dilakukan sebelum proses elusi dengan tujuan untuk mencari fase gerak yang dapat memisahkan parasetamol dalam sampel dengan baik. Pemilihan sistem pelarut yang dipakai pada KLT didasarkan atas prinsip like dissolves like yang memisahkan sampel berdasarkan kepolarannya.Fase diam Silika Gel $\mathrm{F}_{254}$ memiliki sifat polar, sehingga fase gerak yang digunakan harus memiliki prbedaan kepolaran dengan fase diam tersebut.
Fase gerak yang baik adalah yang memberikan nilai Rf antara 0,3 dan 0,7 (Stahl, 1985). Berdasarkan pada hasil optimasi fase gerak, didapatkan hasil fase gerak yang memenuhi syarat tersebut, yaitu kloroform:etanol (9:1) dengan nilai Rf 0,38 (Gambar 1). Sedangkan elusi dengan komposisi fase gerak diklorometana:metanol dengan perbandingan 4:1 menghasilkan nilai Rf yang tinggi, yaitu sebesar 0,92 . Hal ini disebabkan oleh senyawa target memiliki kepolaran yang rendah. Fase diam bersifat polar dan senyawa yang kurang polar tidak akan tertahan kuat pada fase diam sehingga menghasilkan jarak tempuh senyawa yang jauh dan menghasilkan nilai $\mathrm{Rf}$ yang tinggi.

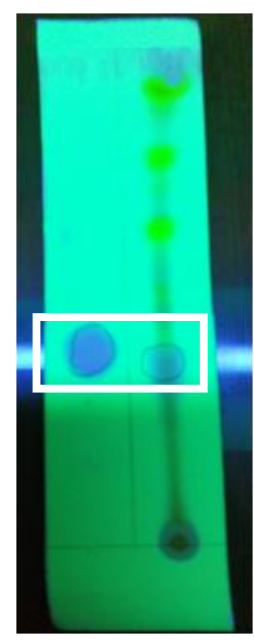

\section{Gambar 1. Hasil pemisahan kromatografi lapis tipis dengan fase gerak kloroform:etanol (9:1)}

Sampel jamu pegal linu hasil sampling yang terpilih selanjutnya dianalisis secara kualitatif menggunakan Kromatografi Lapis Tipis. Penotolan sampel pada lempeng KLT disarankan sebanyak $1 \mu \mathrm{l}$. Jika lebih dari $1 \mu \mathrm{l}$, bercak akan menyebar terlalu jauh sehingga pengelusian kurang optimal [17].

Berdasarkan pada hasil elusi, didapatkan nilai $\mathrm{Rf}$ larutan standar parasetamol sebesar 0,430 . Sampel yang positif mengandung parasetamol ditandai dengan sampel yang memiliki nilai $\mathrm{Rf}$ yang sama atau mendekati \pm 5
\% dengan nilai Rf parasetamol. Sampel tersebut adalah sampel A dengan nilai Rf 0,430; sampel $\mathrm{D}$ dengan nilai $\mathrm{Rf} 0,430$; sampel $\mathrm{E}$ dengan nilai Rf 0,415; sampel $F$ dengan nilai Rf 0,415; sampel $\mathrm{H}$ dengan nilai $\mathrm{Rf} 0,415$; sampel $\mathrm{Q}$ dengan nilai $\mathrm{Rf} 0,430$ dan sampel $\mathrm{S}$ dengan nilai $\operatorname{Rf} 0,430$. Hasil elusi parasetamol dalam sampel jamu pegal linu dapat dilihat pada Gambar 2. 


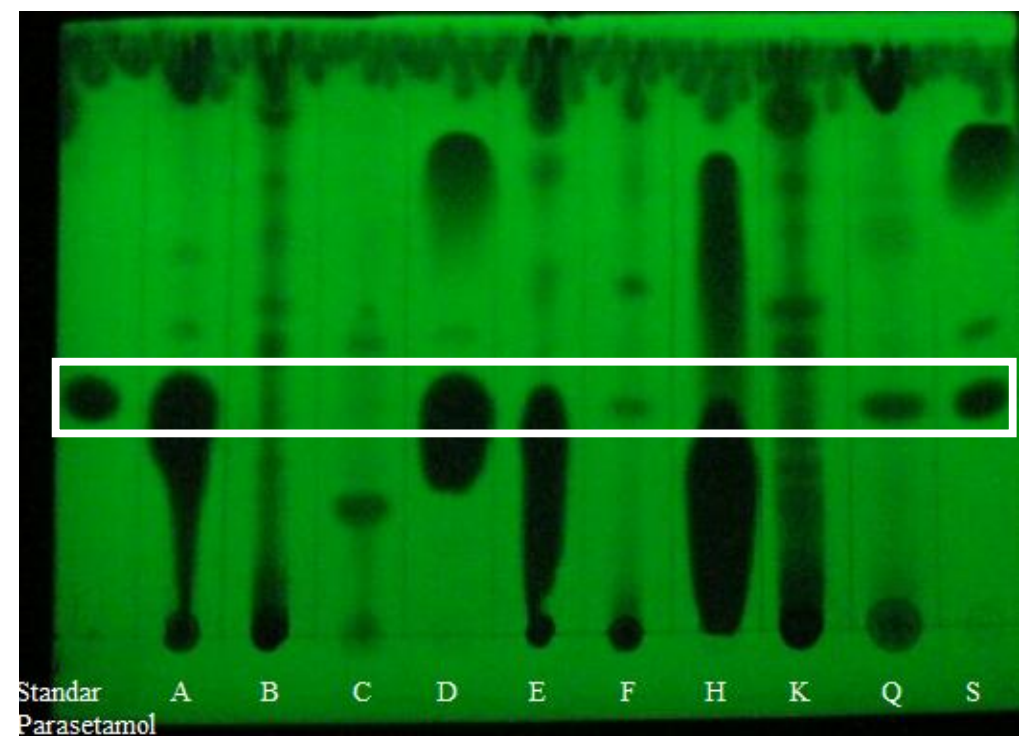

Gambar 2. Hasil elusi parasetamol dalam sampel jamu pegal linu

Berdasarkan pada Gambar 2, beberapa sampel memiliki bercak yang tailing sehingga sulit membedakan antara bercak parasetamol dan bercak jamu itu sendiri.Bercak yang tailing dapat disebabkan karena penotolan sampel terlalu banyak, sehingga zat pada fase diam lebih besar dibandingkan dengan kemampuan fase gerak untuk membawa zat-zat tersebut. Dengan demikian, zat yang ditotolkan akan berinteraksi dengan fase diam [18].Untuk meyakinkan adanya parasetamol dalam jamu, maka dilakukan adisi standar.

\section{Hasil Analisis Kuantitatif Parasetamol}

Penentuan persentase kadar parasetamol yang terkandung dalam jamu pegal linu, dilakukan dengan analisis kuantitatif menggunakan Spektrofotometri UV-Vis.
Hal yang pertama dilakukan dalam analisis kuantitatif adalah melakukan penentuan panjang gelombang maksimum parasetamol. Pada panjang gelombang maksimum, serapannya juga maksimum sehingga pergeseran sedikit pada kurva serapan tidak menyebabkan serapan molar yang terlampau jauh dan menghasilkan pengukuran yang lebih akurat [19].Berdasarkan pada hasil yang diperoleh, panjang gelombang maksimum parasetamol terdapat pada panjang gelombang $248 \mathrm{~nm}$.

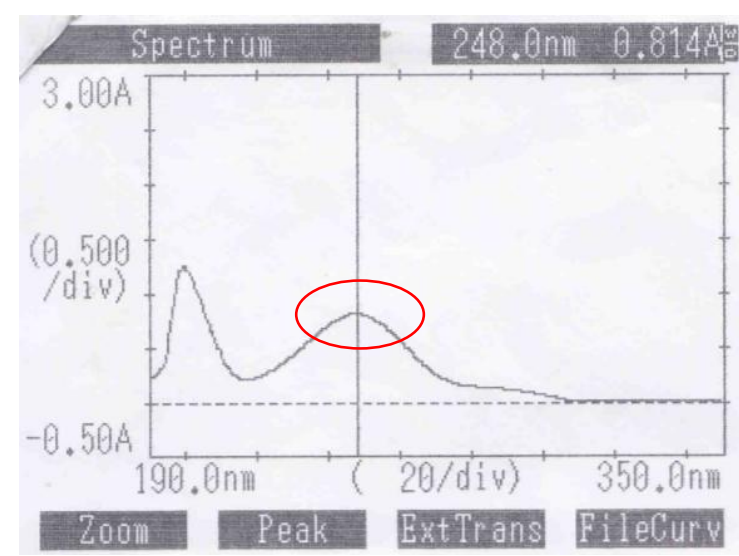

Gambar 3.Panjang gelombang maksimum parasetamol. 


\section{Hasil Optimasi Waktu Maserasi Jamu Simulasi}

Optimasi waktu maserasi parasetamol dalam jamu pegal linu dilakukan untuk mendapatkan waktu maserasi yang optimal sehingga senyawa obat parasetamol dalam jamu dapat terekstraksi secara optimal dan menghasilkan kadar yang optimal pula. Pelarut yang digunakan dalam proses maserasi adalah etanol karena menurut Martindale (2009), senyawa obat parasetamol lebih mudah larut dalam etanol dengan perbandingan 1:7 dibandingan dalam air (1:70), aseton (1:13) dan $\mathrm{NaOH} \quad 1 \quad \mathrm{~N}$ (1:15) sehingga etanol dapat memisahkan senyawa obat parasetamol dari komponen jamu pegal linu dengan baik [20].

Pemisahan parasetamol dalam jamu pegal linu disebabkan saat sampel jamu dilarutkan dalam etanol, etanol akan menembus dinding sel sampel dan masuk ke dalam sel sampel yang mengandung senyawa parasetamol dan terjadi pelarutan. Perbedaan konsentrasi menyebabkan terjadinya difusi sehingga larutan etanol yang terpekat (di dalam sel) akan keluar dan berusaha mencari kesetimbangan antara konsentrasi parasetamol di luar dan di dalam sel [21]. Untuk mempercepat proses tersebut, maka dilakukan pengadukkan maserasi oleh alat magnetic stirrer pada kecepatan $560 \mathrm{rpm}$ dan variasi waktu yang digunakan adalah 30,60 , 90, 120, 150 dan 180 menit. Kecepatan pengadukkan disesuaikan dengan kondisi sampel dan wadah untuk proses maserasi. Pengadukkan yang terlalu tinggi akan menahan perpindahan massa dari padatan ke pelarut dan membentuk emulsi serta padatan kecil yang sulit diendapkan [22]. Kecepatan pengadukkan yang rendah membuat pengadukkan kurang optimal.

Hasil maserasi disaring untuk memisahkan bahan-bahan lain yang tidak larut dalam etanol dan menghindari faktor galat.Hubungan antara kadar parasetamol dalam jamu simulasi terhadap waktu maserasi dapat dilihat pada Gambar 4.

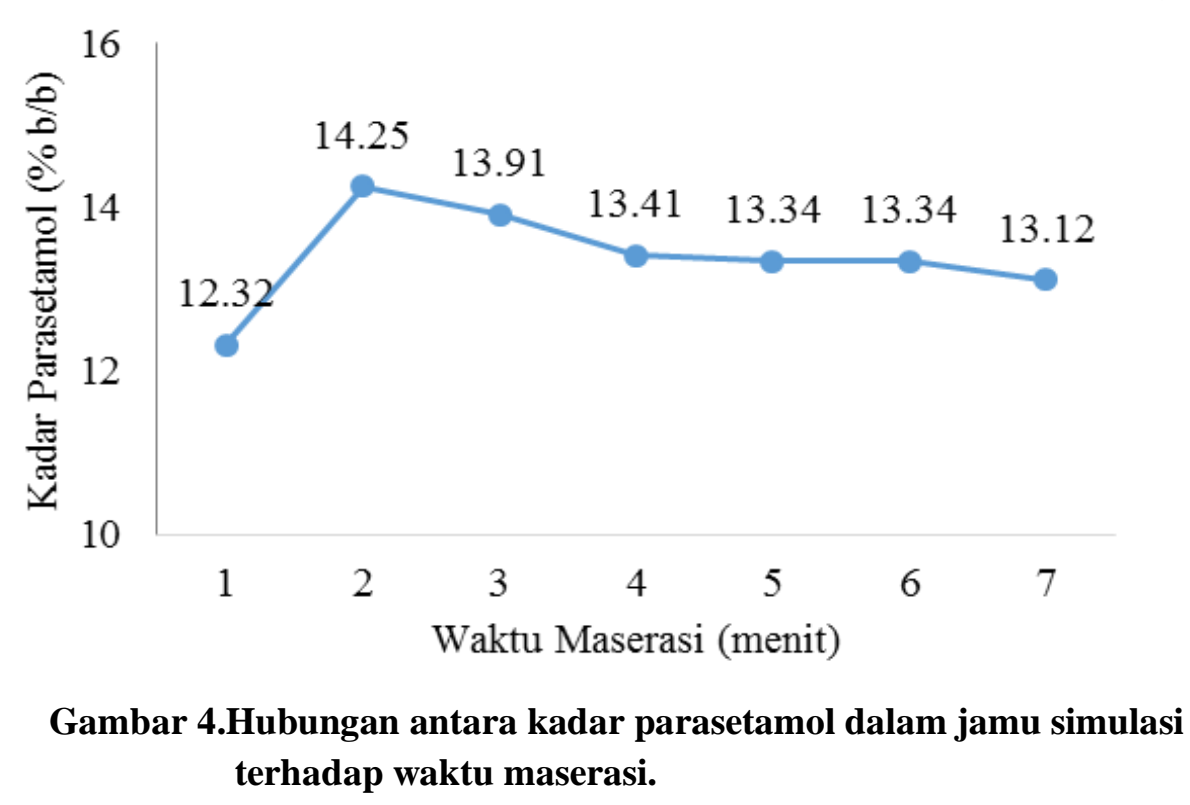

Waktu maserasi yang menghasilkan nilai absorbans tertinggi adalah waktu optimal maserasi parasetamol dalam jamu pegal linu. Nilai absorbans yang didapat kemudian digunakan untuk perhitungan persentase kadar parasetamol dalam sampel jamu pegal linu.Berdasarkan pada Gambar 4, jamu simulasi memiliki waktu maserasi optimal selama 30 menit. Hal tersebut ditandai dengan besarnya jumlah persentase kadar parasetamol yang diperoleh, yaitu 14,25\% (b/b).

Uji perolehan kembali kemudian dilakukan untuk mendapatkan besar kehilangan zat selama proses percobaan dan mengetahui keakuratan metode yang digunakan. Berdasarkan pada perhitungan, didapatkan hasil uji perolehan kembali sekitar 86,05 \% yang berarti ada sekitar 13,94\% zat yang hilang selama proses perlakuan. Hasil perolehan kembali tersebut dapat dikatakan baik, namun tidak memenuhi persyaratan sehingga belum dapat dikatakan akurat. Menurut Harmitta (2006) syarat perolehan kembali harus didapatkan antara 98,0 $\%$ dan $102,0 \%$ [23]. 
Hasil Optimasi Waktu Maserasi dan Analisis Kuantitatif Sampel

Masing-masing sampel jamu pegal linu yang positif mengandung parasetamol pada analisis kualitatif, ditentukan waktu maserasi yang optimal seperti yang telah dilakukan pada jamu simulasi.Hasil Waktu optimal maserasi sampel jamu pegal linu dapat dilihat pada Gambar 5.

Berdasarkan pada Gambar 5, terdapat perbedaan waktu optimum pada masing-masing jamu pegal linu.Jamu simulasi pegal linu memiliki waktu maserasi yang optimum pada waktu 30 menit.Sampel jamu D, F dan S juga memiliki waktu maserasi yang optimum pada waktu 30 menit. Sampel jamu yang memiliki waktu optimum selama 60-90 menit, yaitu sampel jamu A, E dan Q. Hal tersebut dapat disebabkan bentuk ukuran granul yang lebih besar dan kasar dibandingkan dengan sampel D, F dan S. Sampel H memiliki waktu optimum maserasi yang paling lama, yaitu 120 menit karena sampel tersebut memiliki ukuran granul yang lebih besar dan kasar dibandingkan dengan sampel A, E dan Q. Waktu optimasi sampel didominasi oleh rentang waktu antara 30-90 menit.Sehingga, diketahui bahwa sampel jamu pegal linu yang tersebar memiliki waktu maserasi yang optimal pada rentang waktu antara 30-90 menit.

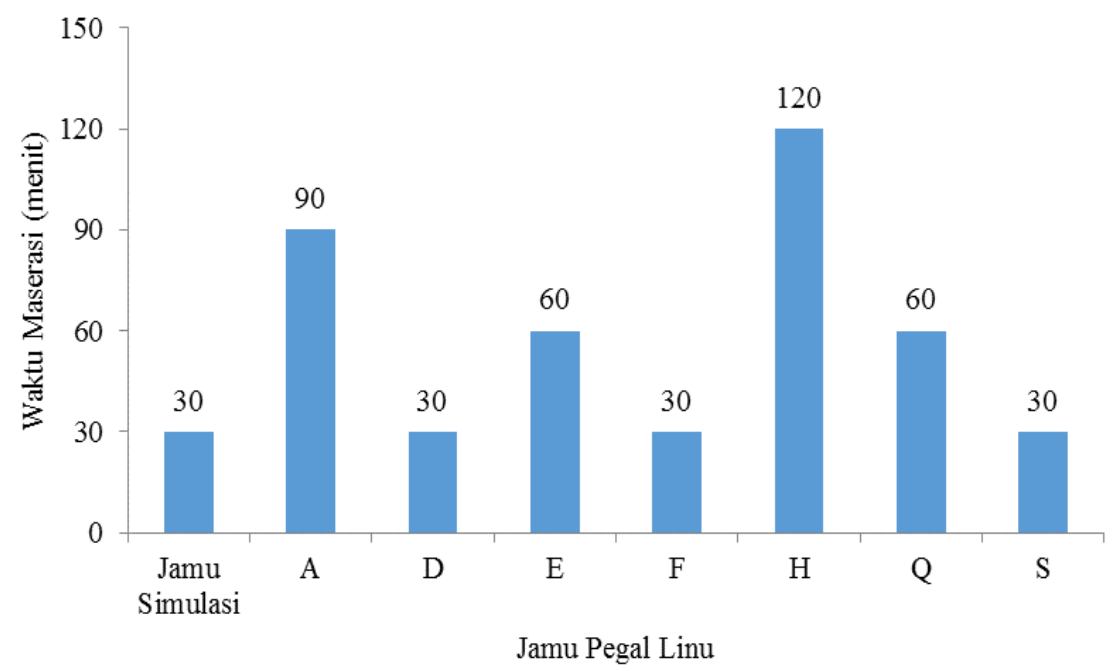

Gambar 5.Hasil waktu optimal maserasi sampel jamu pegal linu.

Perbedaan hasil waktu optimum maserasi dan kadar sampel dapat disebabkan adanya perbedaan kehalusan bentuk sediaan dan komposisi dalam setiap jamu yang dianalisis. Semakin kecil ukuran partikel, semakin besar luas bidang kontak antara sampel dan pelarut sehingga mempercepat penetrasi pelarut ke dalam bahan yang akan diekstrak dan mempercepat waktu ekstraksi [22]. Selain itu, faktor-faktor yang mempengaruhi proses maserasi diantaranya ukuran partikel, pelarut, intensitas pergerakan simplisia dan pelarut (pengadukkan), waktu maserasi dan interaksi substansi terlarut dengan material tanaman lain yang tidak terlarut [22].

Kadar parasetamol dalam masing-masing sampel jamu juga bervariasi, yaitu antara 2.00$23.00 \%$. Kadar optimal pada setiap jamu pegal linu dapat dilihat pada Gambar 6. Metode maserasi dapat digunakan untuk mengekstraksi parasetamol dalam jamu pegal linu karena semua sampel menghasilkan kadar antara 2,49-
$22,33 \%$. Hal tersebut juga menunjukkan bahwa jamu pegal linu yang beredar dengan kode produk A, D, E, F, H, Q dan S tidak memenuhi Peraturan Menteri Kesehatan Republik Indonesia No. 007 Tahun 2012 tentang Registrasi Obat Tradisional Pasal 7 ayat 1 yang menyatakan bahwa obat tradisional dilarang mengandung bahan kimia obat yang merupakan hasil isolasi atau sintetik yang berkhasiat obat.

Setelah mengalami waktu maserasi yang optimal dan pada waktu yang lebih lama, sampel jamu mengalami penurunan persentase kadar. Semakin lama waktu maserasi dan pengadukkan, maka akan terjadi penurunan laju kesetimbangan. Hal tersebut terjadi akibat adanya interaksi substansi terlarut dengan material tanaman lain yang tidak terlarut dan mengakibatkan parasetamol kembali menempel pada permukaan sampel jamu sehingga persentase kadar menurun [24]. Waktu maserasi dan pengadukkan yang terlalu lama dapat menyebabkan terjadinya penempelan 
parasetamol yang sudah larut dari serbuk yang halus ke parasetamol yang belum larut pada serbuk kasar. Dengan bantuan pengadukkan, pada waktu maserasi 120 menit semua parasetamol dalam serbuk kasar dapat larut lebih optimal dan menghasilkan persentase kadar yang optimal.

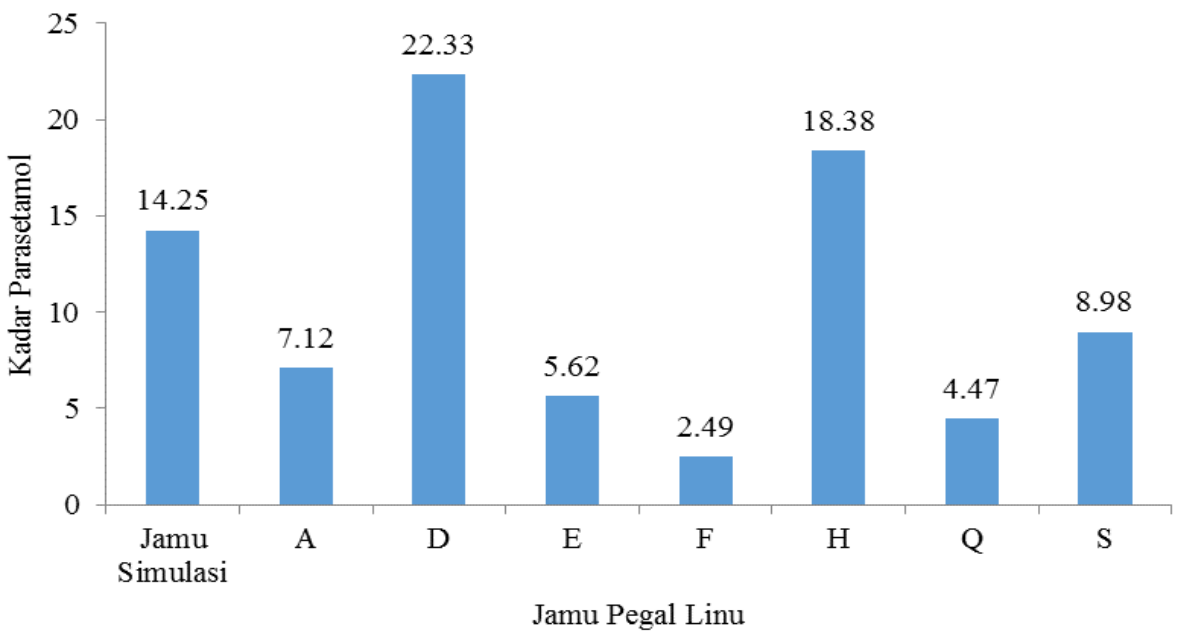

Gambar 6. Kadar optimal maserasi parasetamol sampel jamu pegal linu.

\section{SIMPULAN}

Berdasarkan penelitian yang dilakukan, terdapat 7 dari 10 sampel jamu pegal linu yang beredar di wilayah Bogor Barat yang positif mengandung parasetamol. Waktu maserasi 0-30 menit optimum untuk jamu simulasi, sampel jamu $\mathrm{D}, \mathrm{F}$ dan $\mathrm{S}$ dengan kadar sebesar 2,49 hingga $22,33 \%$. Waktu maserasi selama $60-90$ menit optimum untuk sampel A, E dan Q

\section{DAFTAR PUSTAKA}

[1] [BPOM] Badan Pengawasan Obat dan Makanan. 2010. Acuan Sediaan Herbal,

Volume kelima edisi pertama. Jakarta: Direktorat OAI.

[2] Handayani, L., Suharmiati. 2006.

Meracik Obat Tradisional Secara

Rasional. Depok: Agromedia.

[3] [BPOM] Badan Pengawasan Obat dan Makanan Republik Indonesia. 2015. Bahan Kimia Obat Dalam Obat Tradisional Dan Suplemen Kesehatan Ancaman Bagi Kesehatan Masyarakat. www.pom.go.id. [7 Feb 2016].

[4] Tjay, K. Rahardja. 2007. Obat-Obat Penting. Jakarta: PT Elex Media Komputindo.

[5] Syadawi, A. 2012. Identifikasi Beberapa Senyawa Analgetik dalam Jamu Pegal dengan kadar sebesar 4,47 hingga 7,12\%. Sampel $\mathrm{H}$ memiliki waktu maserasi optimum selama 120 menit dengan kadar sebesar 18,38 $\%$. Waktu optimasi maserasi sampel didominasi oleh rentang waktu antara 30-90 menit.Oleh karena itu, diketahui bahwa sampel jamu pegal linu yang tersebar memiliki waktu maserasi yang optimal pada rentang waktu antara 30-90 menit.

Linu yang Beredar di Kota Padang [Skripsi]. Padang: Fakultas Farmasi Universitas Andalas.

[6] Anggreani, D.L, Rusdi, B., Aprilia, H.W. 2015.Pengembangan Metode Analisis Parasetamol dan Deksametason Pada Jamu Pegal Linu Menggunakan Metode Ekstraksi Fasa Padat dan Kromatografi Cair Kinerja Tinggi.ISSN 24606472.Prosiding Penelitian Sivitas Akademika Unisba. Bandung: Fakultas MIPA Jurusan Farmasi Universitas Islam Bandung.

[7] Agoes, G. 2007. Teknologi Bahan Alam. Bandung: Institut Teknologi Bandung.

[8] Moffat, A.C., Osselton, M.D., Widdop, B. 2011. Clarke's Analysis of Drugs and Poisons in Pharmaceutical, Body Fluids 
and Post Mortem Material, Fourth Edition. London: Pharmaceutical Press.

[9] Sudiarto, D. 1999. Uji Obat Antiinflamasi Non Steroid dalam Jamu Pegal Linu Secara Kromatografi Lapis Tipis [Skripsi]. Depok: Jurusan Farmasi FMIPA Universitas Indonesia.

[10] Dinas Kota Bogor. 2016. Profil Kecamatan dan Kelurahan Kota Bogor. http://profilwilayah.kotabogor.go.id/inde x.php/bogor-barat. [6 Maret 2016]

[11] [Depkes] Departemen Kesehatan. 2014. Farmakope Indonesia V. Jakarta : Departemen Kesehatan Republik Indonesia.

[12] Syarippudin, M. 1997. Analisis Kortikosteroid dalam Jamu Pegal Linu [Skripsi]. Depok: Jurusan Farmasi FMIPA Universitas Indonesia.

[13] Stahl, E. 1985. Analisis Obat Secara Kromatografi dan Mikroskopi. Padmawinata, K., Soediro, I., penerjemah. Bandung: ITB

[14] Naid, T., Kasim, S., Pakaya, M. 2011. Penetapan Kadar Parasetamol Dalam Tablet Kombinasi Parasetamol Dengan Kafein Secara Spektrofotometri Ultraviolet-Sinar Tampak. Majalah Farmasi dan Farmakologi, Vol. 15, No. 2, Juli 2011: 77-82. Makassar: Fakultas Farmasi Universitas Hasanuddin.

[15] Supranto, J. 2000. Statistik Teori dan Aplikasi Edisi VI. Jakarta: Erlangga.
[16] Watson, D.G. 2005. Pharmaceutical Analysis. Edisi II. Glasglow : University of Strathclyde.

[17] Gandjar, I.G, Rohman, A. 2007. Kimia Farmasi Analisis. Yogyakarta: Pustaka.

[18] Sudarmadji, S., haryono, B., Suhardi. 2007. Analisa Bahan Makanan dan Pertanian. Yogyakarta: Liberty.

[19] Day, R.A, Underwood, A.L. 1986. Analisis Kimia Kuantitatif. Edisi Kelima. Jakarta: Airlangga.

[20] Martindale, W. 2009. The Extra Pharmacopea, $36^{\text {th }}$ Edition. London: The Pharmaceutical Press.

[21] Ansel, H.C. 1989. Pengatar Bentuk Sediaan Farmasi.Edisi 4. Jakarta: UI Press.

[22] Treybal, R.E. 1980. Mass Transfer Operations, 3rd Edition. New York: McGraw-Hill Companies. pp. 35-36.

[23] Harmita. 2006. Analisis Fisikokimia. Depok: Departemen Farmasi Fakultas Matematika dan Ilmu Pengetahuan Alam Universitas Indonesia.

[24] Skoog, D.A., West, D.M., Holler, F.J. 2002. Fundamental of Analytical Chemistry, 8th ed. New York: Thomas Brooks Cole. 